\title{
The optical and physical properties of atmospheric aerosols over the Indian Antarctic stations during southern hemispheric summer of the International Polar Year 2007-2008
}

\author{
Jai Prakash Chaubey, K. Krishna Moorthy, S. Suresh Babu, and Vijayakumar S. Nair \\ Space Physics Laboratory, Vikram Sarabhai Space Centre, Thiruvananthapuram, 695 022, India \\ Received: 16 August 2010 - Revised: 24 December 2010 - Accepted: 30 December 2010 - Published: 11 January 2011
}

\begin{abstract}
The properties of background aerosols and their dependence on meteorological, geographical and human influence are examined using measured spectral aerosol optical depth (AOD), total mass concentration $\left(M_{\mathrm{T}}\right)$ and derived number size distribution (NSD) over two distinct coastal locations of Antarctica; Maitri $\left(70^{\circ} \mathrm{S}, 12^{\circ} \mathrm{E}, 123 \mathrm{~m}\right.$ m.s.1.) and Larsemann Hills (LH; $69^{\circ} \mathrm{S}, 77^{\circ} \mathrm{E}, 48 \mathrm{~m}$ m.s.l.) during southern hemispheric summer of $2007-2008$ as a part of the 27th Indian Scientific Expedition to Antarctica (ISEA) during International Polar Year (IPY). Our investigations showed comparable values for the mean columnar AOD at $500 \mathrm{~nm}$ over Maitri $(0.034 \pm 0.005)$ and LH $(0.032 \pm 0.006)$ indicating good spatial homogeneity in the columnar aerosol properties over the coastal Antarctica. Estimation of Angstrom exponent $\alpha$ showed accumulation mode dominance at Maitri $(\alpha \sim 1.2 \pm 0.3)$ and coarse mode dominance at LH (0.7 \pm 0.2$)$. On the other hand, mass concentration $\left(M_{\mathrm{T}}\right)$ of ambient aerosols showed relatively high values $\left(\approx 8.25 \pm 2.87 \mu \mathrm{g} \mathrm{m}^{-3}\right)$ at Maitri in comparison to $\mathrm{LH}$ $\left(6.03 \pm 1.33 \mu \mathrm{g} \mathrm{m}^{-3}\right)$.
\end{abstract}

Keywords. Atmospheric composition and structure (Aerosols and particles)

\section{Introduction}

Antarctica is a unique continent at the extreme south, separated from the other populated continental masses, making it one of the most pristine places on the Earth (Wall, 2005). Due to the pristine characteristics (compared to other snow covered regions like the Arctic or the high altitude mountains in the Northern Hemisphere), it provides an excellent environment to examine the natural and background aerosols in

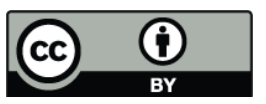

Correspondence to: S. Suresh Babu (s_sureshbabu@vssc.gov.in) the atmosphere over snow and ice. Not only that, the large ice sheet of the Antarctic continent affects atmospheric circulation patterns over this region, which affects the transport and removal of the aerosols particles (Shaw, 1979). In the recent years, with the increase in human interventions (exploratory, scientific and tourism) there is an increase in the emissions of anthropogenic species arising from fossil fuel combustion, both at the research stations as well as those associated with transport. These include atmospheric particles as well (Shaw, 1979; Tomasi et al., 2007; Weller et al., 2008; Chaubey et al., 2010). Antarctic aerosols comprise of mainly sea salt, sulphate, dust, nss sulphate, $\mathrm{NH}_{4}^{+}, \mathrm{NO}_{3}^{-}$, Methane Sulphonate (Minikin et al., 1998; Niemi et al., 2005; Virkkula et al., 2006; Tomasi et al., 2007) and a small amount of efficient absorbing aerosols like black carbon (Bodhaine, 1995; Hansen et al., 2001; Hara et al., 2008; Chaubey et al., 2010). Even a small quantity of absorbing aerosols (anthropogenic or natural) over the highly reflecting snow might enhance the warming of the atmosphere (Chylek and Coakley, 1974; Randles et al., 2004) and the deposition of these particles over the surface of the snow or ice reduces the albedo (Russell et al., 2002; Hansen and Nazarenko, 2004). As such, there is an increased interest and need to investigate the properties of Antarctic aerosols, and their spatial temporal and microphysical properties to understand their climate forcing potential (Valero et al., 1983; Herber et al., 1993; Schwartz and Andreae, 1996; Hatzianastassiou et al., 2004; IPCC, 2007).

Despite the initiation of investigations of aerosols over Antarctica in the early sixties, characterization of various aerosol properties, examination of their inter-relationship and delineating the local effects still remains a hot scientific pursuit (Tomasi et al., 2007) especially due to the scarcity and difficulty of measurements. Aerosols over the coastal and high plateau of Antarctica have quite different physical and chemical properties (Preunkert et al., 2008; Tomasi et al., 2007). The coastal aerosols are strongly influenced by marine environment, while plateau aerosols are only weakly

Published by Copernicus Publications on behalf of the European Geosciences Union. 


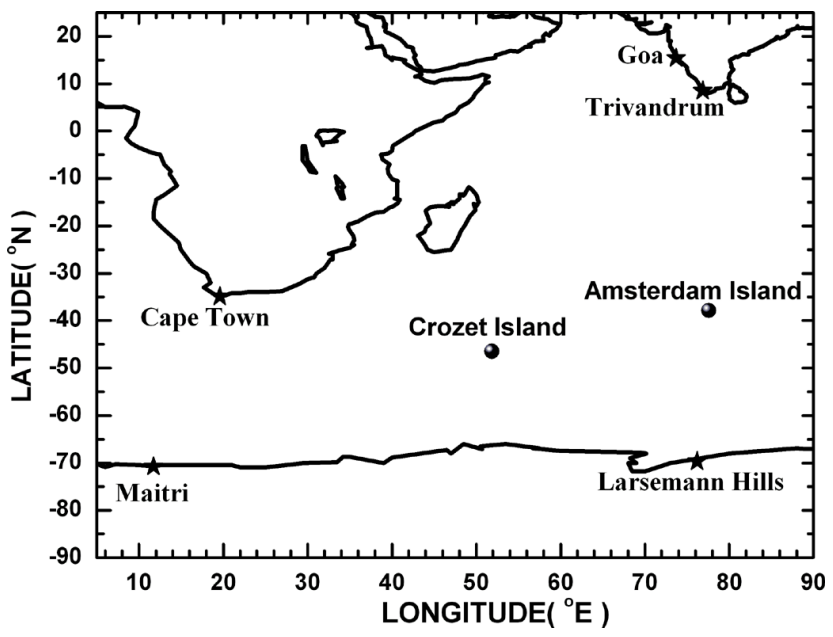

Fig. 1. The geographical location of the Indian stations Maitri, Larsemann Hills (site for third Indian station in Antarctica) and two AERONET stations Amsterdam and Crozet Islands in Southern Ocean. The location of Trivandrum, Goa and Cape Town is also shown.

and episodically influenced by loadings of sea salt particles (during windy conditions that occur especially during winter conditions). They rather contain a predominant fraction of small-sized aerosols, whose presence is favoured by subsidence processes from the free troposphere. The coastal aerosols are important to study the exchange fluxes of particle (natural aerosols) from the ocean and the Antarctic coast. In the Southern Hemisphere, areas south of $35^{\circ} \mathrm{S}$ have no spatial and temporal coverage of ground based measurements except a few island stations established under AErosol RObotic NETwork (AERONET, Holben et al., 1998) and the Antarctic stations. All these make the characterization of Antarctic aerosols and regular and continuous measurements all the more important. The physical and optical properties of aerosols at different Antarctic coastal sites have been examined earlier by Savoie et al. (1992, 1993); Osada et al. (1998); Wagenbach et al. (1998); Hall and Wolff (1998); Jourdain and Legrand (2002); Tomasi et al. (2007). These studies have pointed out the importance of assimilating analogous data from in situ measurements on physical and optical parameters of aerosols for complete characterization of the polar aerosols on the spatial and temporal scales. During the International Polar Year of 2007-2008, as a part of the 27th Indian Scientific Expedition to Antarctica (ISEA), aerosol measurement were carried out between 5 January 2008 to 10 March 2008 at two Indian stations, Maitri and Larsemann Hills (LH) in the coastal East Antarctica. In this paper, we present the aerosol optical depth and mass concentrations measurements carried out during this campaign and make an estimate of the size distributions. The results are examined with those reported for different Antarctic locations and discussed.

\section{Experimental setup, instrument details and database}

Measurements of the physical and optical properties (total mass concentration $\left(M_{\mathrm{T}}\right)$, mass size distribution (MSD) and aerosol optical depth (AOD)) of aerosols were made at Antarctica during the 27th Indian Scientific Expedition to Antarctica (ISEA). The studies were from the Indian Antarctic stations, Maitri $\left(70.77^{\circ} \mathrm{N}, 11.73^{\circ} \mathrm{E}, 123 \mathrm{~m}\right.$ m.s.l.) and Larsemann Hills (LH; $69^{\circ} \mathrm{S}, 77^{\circ} \mathrm{E}, 48 \mathrm{~m}$ m.s.l.), which are well inside the Antarctic circum polar vortex, shown in Fig. 1. The 27 th ISEA commenced from Goa $\left(15.4^{\circ} \mathrm{N}\right.$, $73.7^{\circ} \mathrm{E}$ ) on 6 December 2007 and reached the Indian permanent station Maitri on 4 January 2008 via Cape Town (South Africa, $34.9^{\circ} \mathrm{S}, 19.6^{\circ} \mathrm{E}$ ) onboard an ice class vessel, MV Emerald Sea. Experiments were conducted for about 39 days at Maitri from 5 January 2008 to 13 February 2008. Subsequently the ship sailed off and reached LH (the site for the 3rd Indian station in Antarctica), on 24 February 2008, where the experiments were conducted from 24 February 2008 to 10 March 2008, after which the ship sailed back and reached Goa on 11 April 2008. Also shown in the same figure are two AErosol RObotic NETwork (AERONET) stations namely Amsterdam Island $\left(37^{\circ} \mathrm{S}, 77^{\circ} \mathrm{E}\right)$ and Crozet Island $\left(46^{\circ} \mathrm{S}, 51^{\circ} \mathrm{E}\right)$, in the southern Ocean, which are the permanent stations available close to Antarctica but due north of the Antarctic vortex. The data from these stations are also used in this investigation which would represent both oceanic, and some times advected continental aerosols, depending on the winds. This aspect is important in assessing the radiative impacts of Antarctic aerosols because the radiative forcing efficiency of northern hemispheric continental aerosols, which contains significant amount of anthropogenic component, is high compared to the natural marine aerosols. The two sampling locations, Maitri and LH have distinctively different features. Maitri is situated on Schirmacher oasis, which is near continental ice, $75 \mathrm{~km}$ away from the open ocean and is not a coastal location like LH. Maitri is a rocky area of $\sim 35 \mathrm{~km}^{2}$ and is operational throughout the year since 1989. The thick continental ice is only $500 \mathrm{~m}$ due south off the station. Over the same oasis about $7 \mathrm{~km}$ due east, there is another research station Novo (Russian; $70.82^{\circ} \mathrm{S}, 11.64^{\circ} \mathrm{E}, 120 \mathrm{~m}$ m.s.l.). There is an Airbase $\left(70.99^{\circ} \mathrm{S}, 11.59^{\circ} \mathrm{E}\right) \sim 12 \mathrm{~km}$ southwest to Maitri purely on continental ice and operational during summer. The station Maitri has strength of 75 persons during summer, and 25 in winter. The day to day activities and life are supported by electrical generators working on fossil fuel. In contrast to Maitri, the Larsemann Hills Island is one of the pristine islands, located close to the open Ocean, due east of Maitri with the continental ice $\sim 12 \mathrm{~km}$ due south. Here observations were carried out by 4 to 5 observers who visited the site daily from the ship during day time by helicopter. The instruments are operated mainly on solar power. Moreover, LH is separated by small islands and sea ice (varying from few meters to few kilometres) from the two permanent bases 
in this area, Zhong Shan (Chinese; $\left.69.38^{\circ} \mathrm{S}, 76.38^{\circ} \mathrm{E}\right)$ and Progress (Russian; $69.36^{\circ} \mathrm{S}, 76.38^{\circ} \mathrm{E}$ ), which are almost 9 to $10 \mathrm{~km}$ due northeast and the summer camp, Law Base (Australia) due east, with two persons managing it during summer. As such, on the whole Maitri is a continental station under moderate anthropogenic influence while LH is rather pristine and is more under the influence of marine environments.

Spectral measurements of columnar aerosol optical depth (AOD) at 340, 380, 500, 675 and $870 \mathrm{~nm}$ were made at every 30 min by using a freshly calibrated hand held microtops Sun Photometer (MTOPS, Solar Light Company, USA) whenever the solar disc and its neighbourhoods were free from visible clouds. This instrument is widely used for AOD measurements and its advantages and limitations, as well as the precautions to be taken care have been extensively given in several earlier papers and as such, were not repeated in this manuscript. (Morys et al., 2001; Ichoku et al., 2002; Porter et al., 2001; Moorthy et al., 2005a). The AODs estimated from MTOPS have a typical uncertainty of $\sim 0.01$. A comparative assessment of microtops sun photometers were made at Dome $\mathrm{C}$ in Antarctica with the CIMEL radiometer (CIMEL electronique, France), which are extensively used in more than 200 AERONET stations world wide, showed that the maximum AOD difference was as low as $\sim 0.005$ (Six et al., 2005).

Total mass concentration $\left(M_{\mathrm{T}}\right)$ and mass size distribution of near-surface aerosols (in the ambient) were measured using the Quartz Crystal Microbalance (QCM, model PC2, California Measurements Inc.) cascade impactor which makes size resolved measurements of aerosol mass concentration in its 10 size bins, with $50 \%$ lower cut off diameters at $25 \mu \mathrm{m}, 12.5,6.4,3.2,1.6,0.8,0.4,0.2,0.1$, and $0.05 \mu \mathrm{m}$ for the stages 1 to 10 , respectively. Measurements were made manually at a flow rate of $0.241 \mathrm{~min}^{-1}$ and data are collected every hour, with a sampling time of $5 \mathrm{~min}$. Measurements were restricted to periods when the ambient RH was less than $75 \%$ (with a view of the affinity of Quartz crystal to changes in RH at higher RH levels); a condition which was normally met at the stations, except during blizzards. Following the error budget given by Pillai and Moorthy (2001), the error in the estimated mass concentration was in the range of 10 to $15 \%$ for each measurement. Based on earlier field measurements Moorthy et al. (2005b) have also reported that QCM measured mass concentrations agreed well with those estimated using other sampling methods such as using High Volume Samplers. The QCM was kept near the Dodd beta hut at Maitri, which is away from the zone of routine station activities and almost $300 \mathrm{~m}$ upwind of the generators. The details of the database obtained from MTOPS and QCM at both the sampling locations are given in Table 1 .

Besides the data at the Indian stations, we have used the spectral AOD data obtained from the ship based measurements during the same expedition over Coastal Antarctic Ocean $\left(\mathrm{CAO}, 60-69^{\circ} \mathrm{S}\right)$ using the same Sun Photometer. As

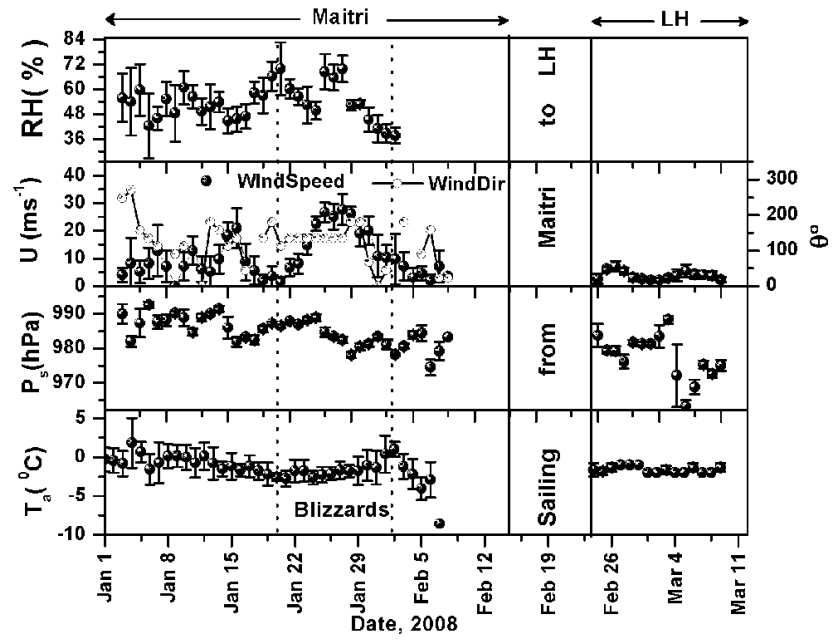

Fig. 2. Graph showing meteorological variations at Maitri and Larsemann Hills. The panels (a), (b), (c), (d) shows the day to day variation of relative humidity, wind speed and direction, pressure and temperature. The solid circles represent the mean value for the day and the line passing through it represents the standard deviation from the mean values of the day. The open circles in the wind parameter panel represent the wind direction. The duration of the ship to travel from Maitri to LH is shown by two vertical lines during which no data was collected. The period between the dotted vertical lines represents the duration of a long blizzard (severe storm condition occurring frequently at Antarctica, governed by high winds, low pressure, snowfall and snow drift) that occurred at Maitri during the observation period.

the sky was cloudy for all the days of the cruise from Maitri to Larsemann Hills we do not have any AOD measurement for this part of the cruise. To see the aerosol properties inside and outside the Antarctic circum polar vortex we also used the level 2 daily mean spectral AOD data from the two AERONET stations, Amsterdam Island and Crozet Island in the southern Ocean as discussed earlier and shown in Fig. 1.

\section{Prevailing meteorology and airmass types during the study}

\subsection{Prevailing meteorology}

Meteorology over the Antarctic region is highly important in understanding the properties, sources and the characteristics of the aerosols because it determines the role and region of transport and the local production of the aerosols over the region. Information on the local meteorology was obtained from the automatic weather stations (AWS), operated regularly by the Indian Meteorological Department (IMD) at Maitri, which yielded air temperature $\left(T_{\mathrm{a}}{ }^{\circ} \mathrm{C}\right)$, relative humidity $(\mathrm{RH})$ and ambient pressure $\left(P_{S}\right)$ at every minute while wind speed $\left(U \mathrm{~ms}^{-1}\right)$ and wind direction $\left(\theta^{\circ}\right)$ are available at every three hour interval. As LH was a recently chosen 
Table 1. Period, number of days of observation and name of the instruments operated at Maitri and Larsemann Hills, in Antarctica during 27th ISEA.

\begin{tabular}{lccllc}
\hline Station name & Latitude $\left({ }^{\circ} \mathrm{S}\right)$ & Longitude $\left({ }^{\circ} \mathrm{E}\right)$ & Period of observation & Instrument operated & No. of days of data \\
\hline Maitri & \multirow{2}{*}{70.8} & \multirow{2}{*}{11.7} & \multirow{2}{*}{ 5 Jan 2008 to 13 Feb 2008 } & $\begin{array}{l}\text { QCM } \\
\text { Sun Photometer }\end{array}$ & $\begin{array}{l}21 \\
20\end{array}$ \\
\hline Larsemann Hills (LH) & \multirow{2}{*}{69.4} & \multirow{2}{*}{76.2} & \multirow{2}{*}{ 24 Feb 2008 to 10 Mar 2008 } & $\begin{array}{l}\text { QCM } \\
\text { Sun Photometer }\end{array}$ & $\begin{array}{c}7 \\
3\end{array}$ \\
\hline
\end{tabular}

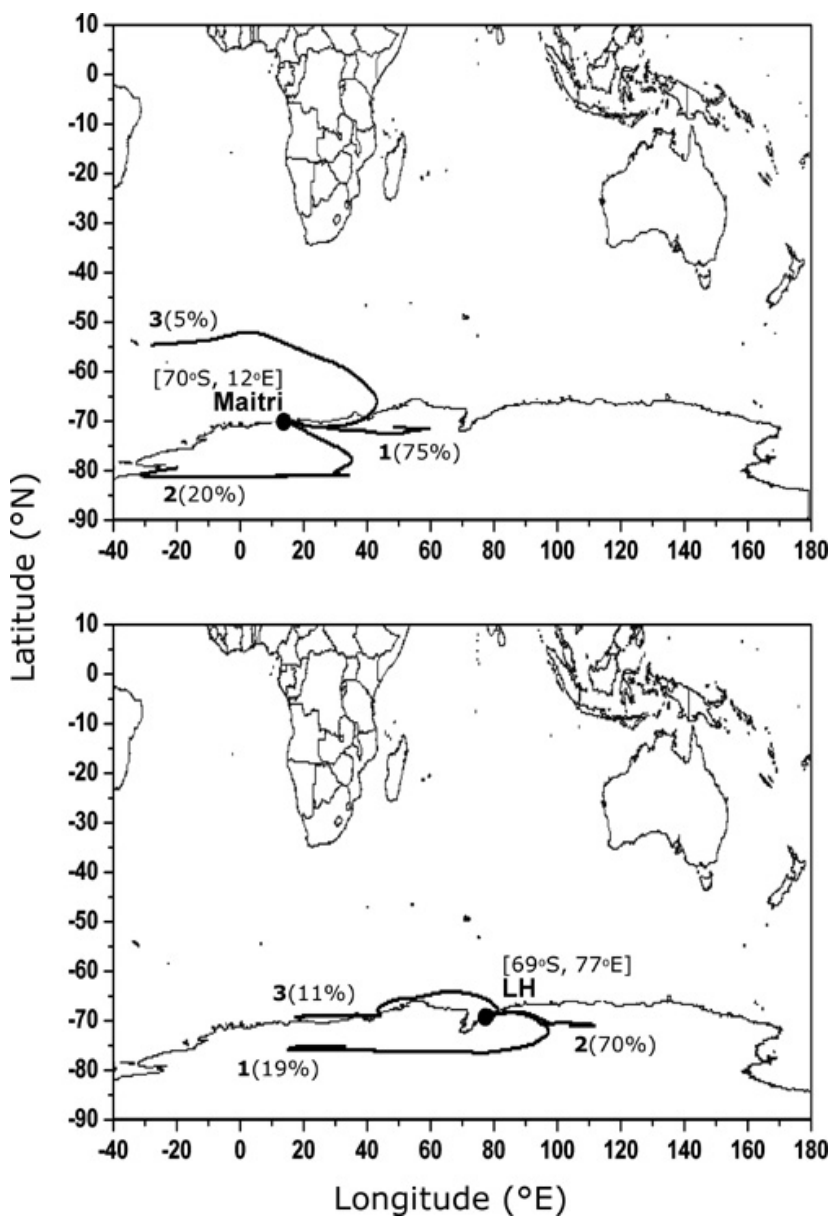

Fig. 3. The cluster mean of the 7 days HYSPLIT airmass back trajectories over Indian Antarctic stations, Maitri and LH for the entire summer and autumn season (1 December 2007 to 31 March 2008). The percentage contribution of the number of trajectories in each cluster to the total number of trajectories at each location is also given.

base for India's third permanent station, there were no permanent setup such as AWS during the study period and as such we used the AWS data onboard the ship, which was anchored $\sim 15 \mathrm{~km}$ due north to the station, as the representative values for LH. The daily mean meteorological features of
Maitri and the LH during the observation period are shown in Fig. 2, where the solid circles show the daily average values and the error bars passing through them are the standard deviations. Though the prevailing meteorology broadly did not differ between Maitri and LH, there were meso-scale differences which are clearly seen in the figure. These meso scale differences might produce some impacts on AOD as Maitri and LH are geographically different location and the proximity to the open Ocean is different at both the places.

During the study period at Maitri, the average temperature was $\sim-1.5^{\circ} \mathrm{C}$ ( $\mathrm{min}$ of $-8.6^{\circ} \mathrm{C}$ and $\max$ of $1.8^{\circ} \mathrm{C}$ ), the higher values being observed on the clear sky days. The mean pressure at Maitri was $983 \mathrm{hPa}$; being $\sim 992 \mathrm{hPa}$ during the normal days and decreased to $\sim 963 \mathrm{hPa}$ during the blizzard episode. The pressure drop on 5 February was also due to the stormy condition that prevailed over the station for a short period. Surface winds were calm to moderate $\left(\sim 10 \mathrm{~m} \mathrm{~s}^{-1}\right)$ during the normal clear sky days, and increased, going up to $\sim 28 \mathrm{~m} \mathrm{~s}^{-1}$ during the blizzards. The prevailing winds over the Maitri were generally south-easterly. The surface relative humidity averaged for the full study period was $53 \%$, showing the dryness of the continent. It varied from a low value of $\sim 38 \%$ in normal clear sky days to a comparatively high value of $\sim 70 \%$ during the blizzard days. In comparison, at LH the variation in the temperature were smaller; the daily average temperature being always below zero during the study period, while the winds were generally calm to low $\left(<5 \mathrm{~m} \mathrm{~s}^{-1}\right)$.

\subsection{Airmass reaching Maitri and LH}

With a view of examining the potential advection pathways of aerosols at Maitri and LH, we performed 7-day airmass back trajectory analyses using HYbrid Single Particle Langrangian Intergerted Trajectory (HYSPLIT) model of National Oceanographic and Atmospheric Administration (NOAA) for the Antarctic summer season (DecemberApril) of 2007-2008. The choice of 7 days was made due to the longer lifetime expected for aerosols in this region (Shaw, 1988). The trajectories are estimated for a height of $100 \mathrm{~m}$ above the station, which is well inside the Antarctic boundary layer (typically of $\sim 500 \mathrm{~m}$, Argentini et al., 2005), which though is shallower than typical mid-latitude or 
tropical convective boundary layer, as a result of the persistent stability of the overlying atmosphere (King and Turner, 1997). The cluster mean of the HYSPLIT airmass back trajectories are shown in Fig. 3. The percentage contribution of the number of trajectories in each cluster to the total number of trajectories at each location is also given in the figure which clearly show that, at both the locations (Maitri and $\mathrm{LH})$ for the entire summer season, trajectories were mostly coming from the polar continental regions, and only a few from the nearby oceanic regions, that too during blizzards. At both Maitri and LH, the airmass could be grouped into three clusters, the first one coming from the due east ( $\sim 75 \%$ at Maitri and $70 \%$ at LH) of the location, the second one from the west ( $\sim 20 \%$ at Maitri and $19 \%$ at $\mathrm{LH})$ and the third one from the oceanic regions ( $\sim 5 \%$ at Maitri and $11 \%$ at $\mathrm{LH})$. As such, both locations are influenced by the activities taking place locally in Antarctica especially due to presence of nearby stations.

\section{Results and discussion}

\subsection{Aerosol optical depth}

Temporal variations of the daily mean AOD at $500 \mathrm{~nm}$, estimated by averaging the individual microtops measurements of each day, are shown in top panel of Fig. 4, where the solid circles represent Maitri observation and hollow circles those measured over LH. The vertical lines passing through the circles represent the respective standard deviations. It can be seen (panel a) that over Maitri AOD showed significant day to day variations, that was random in nature. The AOD at $500 \mathrm{~nm}$ showed the peak value of 0.046 (on 13 January 2008) and least value of 0.026 (on 8 February 2008) with an average of $0.034 \pm 0.005$ for the full study period at Maitri. Based on the measurements made during 20th ISEA from Maitri, Gadhavi and Jayaraman (2004) reported a mean AOD value of $0.036 \pm 0.018$ at $400 \mathrm{~nm}$ with similar random variations observed in the present study. The two mechanisms which might be contributing to this are

1. marine particles (sea salt) and dust particles from the oasis; both produced and transported by the winds, and

2. those produced by the local activities at Maitri and near by stations

As Maitri is situated on an oasis and experiences a fair amount of local station activities during the summer period, both the mechanisms would be significant. Moreover, advection from the neighbouring stations lying upwind, movement of men and transport of goods (more frequent during Antarctic summer at all stations) also contribute to the local (regional) aerosol abundance and to the day to day variations in the AOD. Nevertheless, the average AOD values measured over Maitri were comparable to

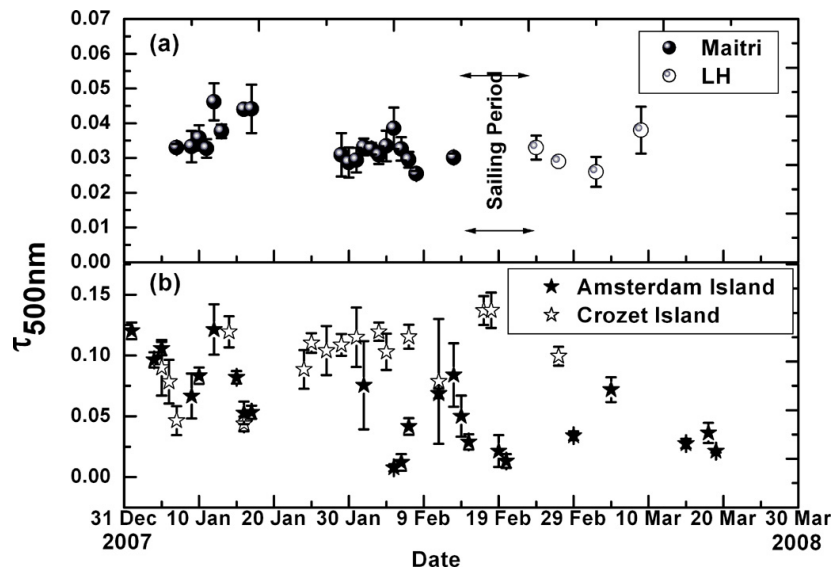

Fig. 4. Daily mean aerosol optical depth $(\tau)$ at $500 \mathrm{~nm}$ for the Maitri and LH in the top panel (a) and those of Amsterdam and Crozet Island in bottom panel (b), where in the top panel, solid and open circles represent Maitri and LH respectively. The vertical line passing through them as standard deviation from the mean value. In the bottom panel the solid stars represent the daily mean AOD over Amsterdam Island and the open stars represent the AOD over Crozet Island.

those measured over $\mathrm{LH}$ (within the standard deviation), except that, over LH, the AOD depicted smaller day to day variations, remaining between 0.026 and 0.038 with an average of $0.032 \pm 0.006$. It may also be noted that AOD measurements were available only for 4 days (a total of 84 measurements) at LH due to the frequent cloudy skies during the measurement period. Nevertheless, these formed the first ever measurements of AOD from this region of Antarctica. It is also interesting to note that the monthly mean value of AOD at $550 \mathrm{~nm}$ for March (8 days of data are available from 2 to 21 March, 2008) obtained from MODIS satellite sensor, (http://gdata1.sci.gsfc.nasa.gov/daac-bin/G3/gui.cgi? instance_id=MODIS_DAILY_L3) over the open ocean close to $\mathrm{LH}$ during the study period is found to be $0.33 \pm 0.005$ is comparable to the mean value observed in the present study. AOD values over Maitri were measured in JanuaryFebruary whereas at LH the measurements were made at the end of February and beginning of March. The slight decrease in AOD (from Maitri to LH), although not much significant, can be attributed to the decrease in the aerosol loading over Antarctica as season changes (Shaw, 1988; Wolff and Cachier, 1998; Hara et al., 2005). Notwithstanding this, agreement between AODs at the two locations indicates the prevalence of spatially homogeneity in columnar aerosol abundance at coastal Antarctic atmosphere spatially. This is in contrast to that reported over the populated continental regions of Northern Hemisphere where significant heterogeneity (vertically and spatially) due to elevated aerosol layers are reported frequently (Muller et al., 2001; Satheesh et al., 2008). 
Table 2. Antarctic stations, there features, location and measured optical depth.

\begin{tabular}{|c|c|c|c|c|c|c|c|}
\hline Station name & Type & Country & Location & AOD & $\begin{array}{l}\text { Wavelength } \\
(\mathrm{nm})\end{array}$ & Year & References \\
\hline Maitri & C,LA & India & $71^{\circ} \mathrm{S}, 12^{\circ} \mathrm{E}$ & $\begin{array}{l}0.034 \pm 0.005 \\
0.01 \text { to } 0.1\end{array}$ & $\begin{array}{l}500 \\
400-1000\end{array}$ & $\begin{array}{l}2007-2008 \\
2000-2001\end{array}$ & $\begin{array}{l}\text { Present study } \\
\text { Gadhavi and Jayara- } \\
\text { man (2004) }\end{array}$ \\
\hline Larsemann Hills & C, LA & India & $69^{\circ} \mathrm{S}, 76^{\circ} \mathrm{E}$ & $0.032 \pm 0.006$ & 500 & 2007-2008 & Present study \\
\hline Terra nova Bay & $\mathrm{C}$ & Italy & $76^{\circ} \mathrm{S}, 164^{\circ} \mathrm{E}$ & $0.01-0.0$ & 500 & 2005 & Tomasi et al. (2007) \\
\hline Aboa & I, LA & Finland & $72^{\circ} \mathrm{S}, 96^{\circ} \mathrm{E}$ & $0.035-0.063$ & 500 & 2000 & $\begin{array}{l}\text { Wehrli (2005), } \\
\text { Tomasi (2007) }\end{array}$ \\
\hline Neumayer & $\mathrm{C}, \mathrm{LA}$ & Germany & $71^{\circ} \mathrm{S}, 8^{\circ} \mathrm{W}$ & 0.044 & 500 & 1999-2002 & Weller et al. (2008) \\
\hline Mirny & C,LA & Russia & $67^{\circ} \mathrm{S}, 93^{\circ} \mathrm{E}$ & $\begin{array}{l}0.01-0.02 \\
0.03\end{array}$ & $\begin{array}{l}1000 \\
500\end{array}$ & $\begin{array}{l}1980-1988 \\
2006\end{array}$ & $\begin{array}{l}\text { Radionov (1994) } \\
\text { Tomasi et al. (2007) }\end{array}$ \\
\hline Kohnen & $\mathrm{I}, \mathrm{HA}$ & Germany & $75^{\circ} \mathrm{S}, 0^{\circ} \mathrm{E}$ & 0.013 & 500 & 1999-2002 & Tomasi et al. (2007) \\
\hline Dome C & I, HA & Italy/France & $75^{\circ} \mathrm{S}, 123^{\circ} \mathrm{E}$ & $\begin{array}{l}0.02 \\
0.007\end{array}$ & $\begin{array}{l}500 \\
870\end{array}$ & 2003-2004 & Tomasi et al. (2007) \\
\hline South Pole & I, LA & USA & $90^{\circ} \mathrm{S}$ & $0.01-0.02$ & 1000 & 1958,1962 & $\begin{array}{l}\text { Viehbrock and Flow- } \\
\text { ers (1968) }\end{array}$ \\
\hline McMurdo & C,LA & USA & $78^{\circ} \mathrm{S}, 167^{\circ} \mathrm{E}$ & 0.02 & 1000 & 1978 & Shaw (1982) \\
\hline Maudheim & $\mathrm{C}, \mathrm{LA}$ & Norway & $71^{\circ} \mathrm{S}, 11^{\circ} \mathrm{W}$ & 0.025 & 1000 & $1950-1951$ & Liljequist (1957) \\
\hline George Forster & C,LA & Germany & $71^{\circ} \mathrm{S}, 12^{\circ} \mathrm{E}$ & 0.022 & 1000 & 1988-1991 & Herber et al. (1993) \\
\hline Plateau & I, HA & USA & $79^{\circ} \mathrm{S}, 41^{\circ} \mathrm{E}$ & 0.02 & 1000 & 1969 & Tomasi et al. (2007) \\
\hline
\end{tabular}

C-Coastal, I-Inland, HA-High Altiude, LA-Low Altitude

The storm belts that surrounds Antarctica act as efficient barriers for the migration of aerosols and trace gases from low latitudes (Shaw, 1982) and vice versa. As shown in Fig. 3, during the study period, the airmass arrived at Maitri and LH from the Antarctic continental regions. As such, a major part of aerosols over here might be attributed to local activities. Shirsat and Graf (2009) have shown that in Antarctica $0.004 \mathrm{Tg}$ of $\mathrm{SO}_{2}$ is produced per year from power generation and transportation alone.

Notwithstanding this, the daily mean values seen in our study are significantly lower than the values reported for the different remote and coastal oceanic regions (Smirnov et al., 2002, and references cited therein; Vinoj et al., 2007) outside Antarctica vortex. With a view to comparing our values with those existed over remote southern ocean we examined the daily mean level 2 AOD data from the two AERONET stations (Fig. 1) for the period from 1 January to 31 March 2008 and the temporal variations are shown in the bottom panel of Fig. 4. The solid stars represent the daily mean AOD over Amsterdam Island and the open stars represent the AOD over Crozet Island. At both these stations the AODs depict significant day to day variations which could be due to the high and variable sea surface winds persisting over the southern oceans (Moorthy et al., 2005b). The AODs are also significantly higher than those at Maitri and LH for the period of common data. At Amsterdam Island, AOD values showed a decreasing trend from January to March, with the values becoming comparable to that at Maitri and LH by the end of February/beginning of March. However, this is not true for the Crozet Island (which has a better proximity to the continent of Africa), where the AOD values remained higher and more or less constant from January to March months. The important point to note here is the geographical location of both stations in southern ocean, which are entirely different. Amsterdam is located outside the circumpolar current area and away from the boundary of turbulent oceans (beyond $\sim 40^{\circ} \mathrm{S}$ ) where as Crozet Island is inside the circumpolar current area (which resists any particles exchange from regions inside and outside the current area) and well within the turbulent oceans. This also may be responsible for the high and almost constant AOD over the Crozet Island. The AOD values reported from different locations of Antarctica starting since 1950s are listed in Table 2. It shows that while our values are quite comparable to those at other coastal locations, but slightly higher than the values reported from the inland stations.

\subsection{Spectral variation of AOD}

The mean spectral AODs were estimated for the respective measurement periods, separately for Maitri, LH and for the Coastal Antarctic Ocean $\left(\mathrm{CAO} ; 60^{\circ} \mathrm{S}-69^{\circ} \mathrm{S}\right)$ are shown in Fig. 5a. As the spectral dependence of AOD contains information about aerosol size distribution, which can be inferred in a simplest way by using the Angstrom power law relation of the form (Angstrom, 1964)

$\tau_{p}(\lambda)=\beta \lambda^{-\alpha}$ 


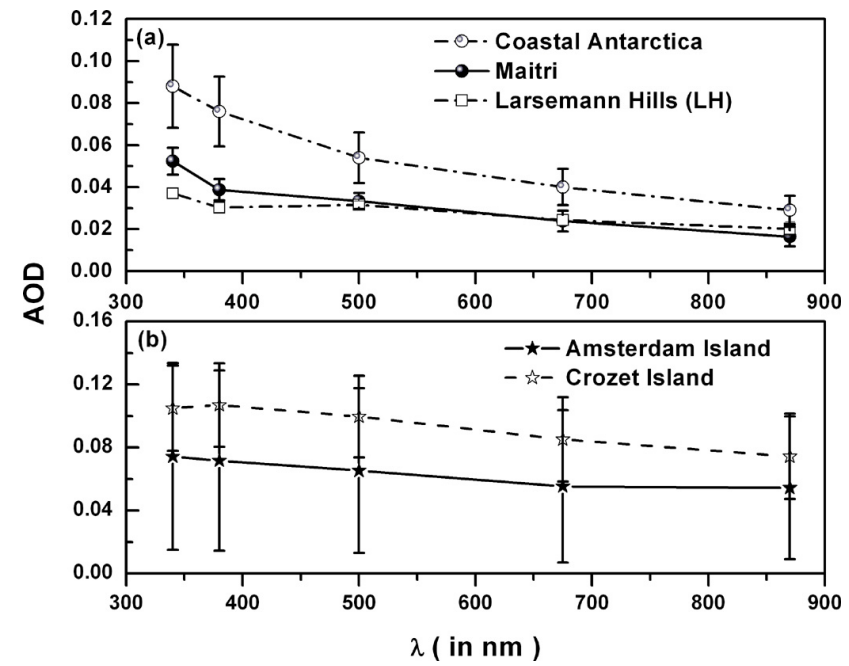

Fig. 5. (a) Mean AOD spectrum for the entire period at Maitri and Larsemann Hills along with the CAO region where open sphere, solid sphere and open square corresponds to CAO, Maitri and $\mathrm{LH}$, respectively. The vertical line passing through the symbol represents the standard deviation from the mean value. (b) Spectral variation at Amsterdam (represented by solid star) and Crozet Island (represented by open stars). The vertical line passing through the symbols are the standard deviation from the mean value.

where $\alpha$ is Angstrom exponent, $\beta$ is the turbidity parameter and $\lambda$ is the wavelength in $\mu \mathrm{m}$. Estimation of $\alpha$ and $\beta$ was done by the least square fitting to the each spectral optical depth measurements in log-log scale. In general, $\alpha>1$ indicate an increased abundance of fine and accumulation mode aerosols (size $<1 \mu \mathrm{m}$ ) in the aerosol size spectrum, while $\alpha<1$ is considered indicative of a coarse mode aerosol (size $>1 \mu \mathrm{m}$ ) dominance. Figure 5a clearly shows that spectral variation is flat for LH compared to Maitri and CAO, indicating aerosol size distribution at Maitri and LH are different. With a view to compare the AOD spectra with further north of the CAO, but outside the Antarctic vortex, the mean AOD spectra for the study period from the AERONET stations are shown in Fig. 5b, where the solid and open stars represents Amsterdam and Crozet island respectively and the vertical lines indicating the corresponding standard deviation. It is found that AOD are spectrally independent which is typical of remote marine environments (Smirnov et al., 2002).

The day-to-day variations of $\alpha$ at CAO, Maitri, LH and the island stations (Amsterdam and Crozet) are shown respectively in the top and bottom panels of Fig. 6, where in the top panel, solid and open circles represents the values at Maitri and $\mathrm{LH}$ and the filled squares represents the daily average values in the CAO. The solid and open stars in the bottom panel represent the values at Amsterdam and Crozet Island respectively. For the study period at Maitri, the daily average $\alpha$ varied from 0.8 to 1.6 with an average of $1.2 \pm 0.3$, which is comparable to the mean value obtained for $\mathrm{CAO}(1.1 \pm 0.09)$,

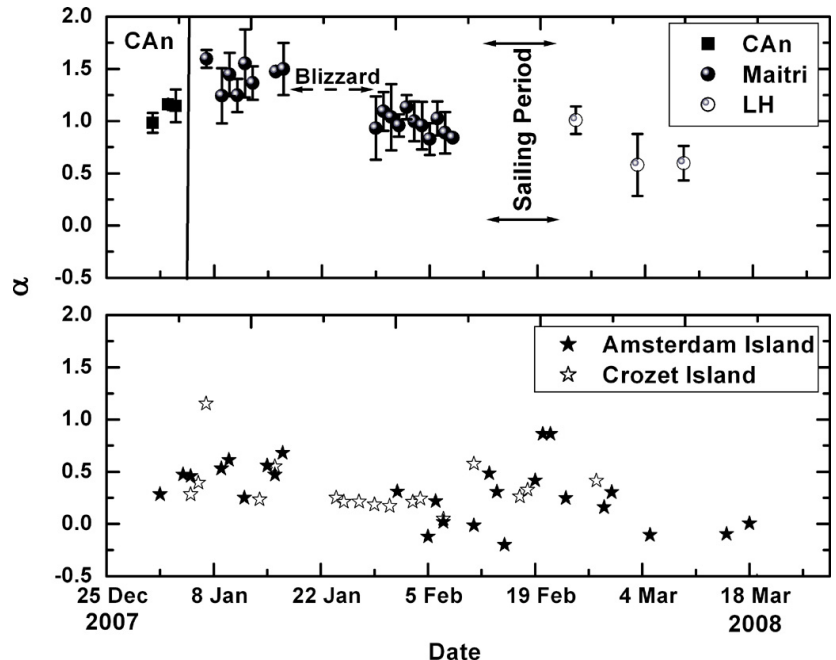

Fig. 6. Daily mean values of Angstrom parameters $\alpha$ at Maitri, LH (in top panel), Amsterdam and Crozet Island (in bottom panel). The vertical line in the top panel shows the standard deviation from the mean values.

whereas for LH it varied from 0.6 to 1 with an average $\alpha$ of $0.7 \pm 0.2$ which is significantly lower than that at Maitri and CAO. The $\alpha$ values over Amsterdam and Crozet Islands are found to be $<0.75$ (with the occasional occurrence of negative values indicating coarse mode abundance) through out the study period.

Angstrom coefficient $\beta$, varied from 0.009 to 0.02 at Maitri (with an average of $0.015 \pm 0.005$ ) and from 0.015 to 0.024 at $\mathrm{LH}$ (with an average of $0.02 \pm 0.004$ ). These values are comparable to the range of values $(0.002-0.1)$ reported by Tomasi et al. (2007) for the different coastal and inland Antarctic station.

During the measurement period over $\mathrm{CAO}$ winds were comparatively calm (inferred from ship AWS data) and the ocean surface was covered (not totally) with sea ice, whereas at LH winds were comparatively higher (average of $5 \mathrm{~ms}^{-1}$ ) and ocean surface was free from sea ice. The decrease in the steepness of AOD spectra (correspondingly lower $\alpha$ ) may be due to the occurrence of high sea surface winds over open Ocean and the consequent production of sea salt particles which are generally larger in size (Fitzgerald, 1991; O'Dowd et al., 1997; Moorthy et al., 1997; Moorthy and Satheesh, 2000; Vinoj and Satheesh, 2003). An examination of the surface wind over the oceanic regions adjacent to the island stations (Amsterdam and Crozet) by using QuickSCAT wind data showed variable winds varying from a minimum of $3 \mathrm{~m} \mathrm{~s}^{-1}$ to maximum of $16 \mathrm{~m} \mathrm{~s}^{-1}$ with an average of $\geq 10 \mathrm{~m} \mathrm{~s}^{-1}$. Similar results depicting the surface wind speed dependence on spectral AOD has been reported over same latitude region by Smirnov et al. (2006) and Vinoj et al. (2007). 


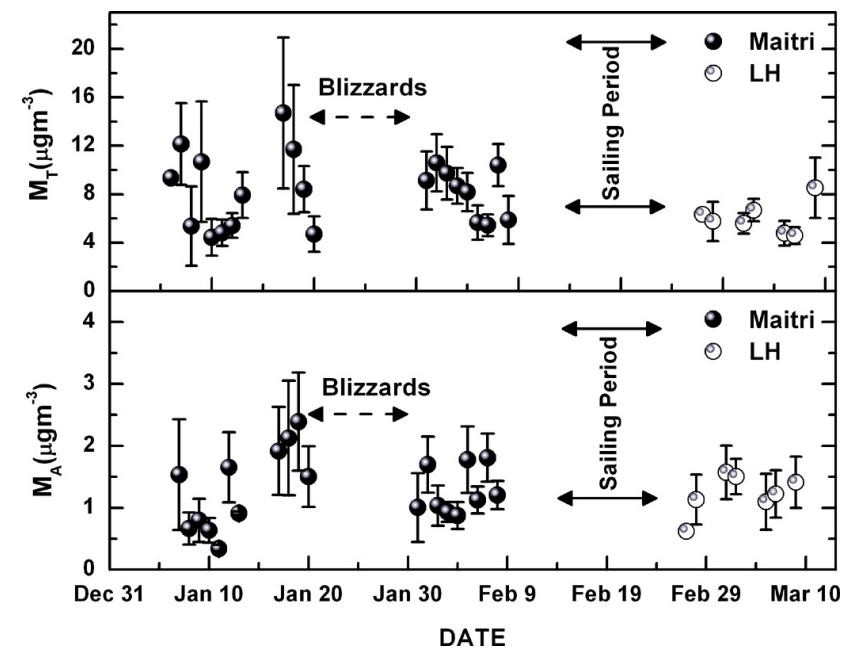

Fig. 7. Daily mean total mass concentration $\left(M_{\mathrm{T}}\right)$ and accumulation mode mass concentration $\left(M_{\mathrm{A}}\right)$. The solid and open circles are daily averages of $M_{\mathrm{T}}$ and $M_{\mathrm{A}}$ for Maitri and LH in top and bottom panel, respectively. The vertical lines passing through the symbol are the standard deviations from the mean values.

The dominance of fine and accumulation particles at Maitri might be due to

1. the enhanced station activities there,

2. pre existing accumulation mode dominant background aerosols in the coastal Antarctic atmosphere as suggested by Herber et al. (1993) and Hara et al. (2005); and

3. those of biogenic species (like methane sulphonate) and non sea salt sulphate (products of dimethyl sulphide) which have been reported during Antarctic summer (Weller et al., 2008).

On the other hand, LH being very near to and surrounded by the open Ocean (free from sea ice) and having a low elevation of just $48 \mathrm{~m}$ m.s.l., it is conducive of being influenced by the local (wind generated) sea salt particles much more than Maitri (almost $75 \mathrm{~km}$ away from the open Ocean). Moreover as the coarse mode sea salt particles get settled faster in comparisons to the fractionated sea salt aerosols and as such the marine airmass reaching Maitri would be strongly deprived of the coarse mode component. This would explain the difference in $\alpha$ between the two stations. From extensive measurements at multiple Antarctic stations, Tomasi et al. (2007) have reported values in the range 0.02 to 2.54 for $\alpha$ at different stations in Antarctica in which the values over the coastal locations varied from 0.5 to 1.2 similar to the values reported in the present study.

\subsection{Mass concentrations of ambient aerosol}

Each measurement of the QCM provided direct information of the total mass concentration, $M_{\mathrm{T}}$ (of particles over the entire size range 0.05 to $25 \mu \mathrm{m}$ ) in unit volume of ambient air, along with the mass concentrations in its each size bin. From the size segregated mass concentrations, accumulation mode mass concentration $\left(M_{\mathrm{A}}\right)$ was determined as the sum of the mass in channels 7 to 10 of the QCM (size range $\leq 0.8 \mu \mathrm{m})$. The individual estimates of $M_{\mathrm{T}}$ and $M_{\mathrm{A}}$ for each day were averaged to get the daily mean values. In Fig. 7, we have shown the day-to-day variations of $M_{\mathrm{T}}$ in top panel and $M_{\mathrm{A}}$ in the bottom panel where the solid circles correspond to the values at Maitri and open circles correspond to LH. The vertical bars through the points represent the corresponding standard deviations. $M_{\mathrm{T}}$ depicted fairly large day-to-day variation at Maitri, from a minimum value of $4.4 \mu \mathrm{g} \mathrm{m}^{-3}$ to a maximum of $14.7 \mu \mathrm{g} \mathrm{m}^{-3}$, with a mean value of $8.25 \pm 2.87 \mathrm{\mu g} \mathrm{m}^{-3}$. Comparatively lower values are found at $\mathrm{LH}$ where it varied from $4.58 \mu \mathrm{g} \mathrm{m}^{-3}$ to $8.53 \mu \mathrm{g} \mathrm{m}{ }^{-3}$ with a mean value of $6.03 \pm 1.33 \mu \mathrm{g} \mathrm{m}^{-3}$ for the study period. While the minimum values at both locations are comparable, showing the homogeneity in the background values over coastal Antarctica. The maximum values are rather higher over Maitri before the blizzard event. The standard deviation in both $M_{\mathrm{T}}$ and $M_{\mathrm{A}}$ at Maitri were quite larger than the deviations at LH, similar to the columnar AOD. While the measured value of $M_{\mathrm{T}}$ with day to day variations over Maitri has been similar to earlier reports by Gadhavi and Jayaraman (2004) PM10 particles, these were higher than the values reported by Mazzera et al. (2001) for $\mathrm{PM}_{10}$ particles at Mc Murdo station, Antarctica. The low variabilities in $M_{\mathrm{T}}$ and $M_{\mathrm{A}}$ at $\mathrm{LH}$ is consistent with the subdued station activities and the absence of any neighbouring stations upwind. Other processes such as troposphere-stratosphere exchange of aerosols is very less effective over Antarctica due to the low pressure in the upper stratosphere that makes wind flow always towards the oceans. Only when the polar vortex breaks down, the exchange of the stratosphere and troposphere air takes place and the aerosols are brought down to the lower troposphere and that too mainly at high latitudes region (Hogan et al., 1979). These aerosols are then transported towards the coastal Antarctica by the katabatic wind and strength of this cycle may contribute significantly in the day to day variation in the ambient mass concentration. Not withstanding the day-to-day variations, the mean values of $M_{\mathrm{T}}$ reported in our study were significantly lower than the values reported for distinct regions between coastal India and coastal Antarctica as listed in Table 3, which reveals a large gradient with higher values in the northern oceanic regions, decreases towards south, showing the highly subdued impacts of anthropogenic activities over Antarctica. 
Table 3. Total mass concentration at Antarctic location and comparison with the off Antarctic coastal and oceanic regions from coastal India to coastal Antarctica.

\begin{tabular}{lcl}
\hline Location & $M_{\mathrm{T}}\left(\mu \mathrm{g} \mathrm{m}^{-3}\right)$ & References \\
\hline \multicolumn{3}{c}{ Antarctic locations } \\
\hline Maitri $\left(71^{\circ} \mathrm{S}, 11^{\circ} \mathrm{E}\right)$ & $8.25 \pm 2.87$ & Present study \\
Larsemann Hills $\left(69^{\circ} \mathrm{S}, 76^{\circ} \mathrm{E}\right)$ & $6.03 \pm 1.33$ & Present study \\
Maitri $\left(71^{\circ} \mathrm{S}, 11^{\circ} \mathrm{E}\right)$ & $9.1 \pm 6$ & Gadhavi and Jayaraman (2004) \\
Mc Murdo $\left(78^{\circ} \mathrm{S}, 167^{\circ} \mathrm{E}\right)$ & $\sim 3.5$ to 4.2 & Mazzera et al. (2000) \\
\hline \multicolumn{1}{c}{ Off Antarctic locations (from coastal India to coastal Antarctica) } \\
\hline Coastal India & 50 to 80 & Moorthy et al. (2005a) \\
Arabian Sea & $16.7 \pm 7$ & Nair et al. (2008) \\
Bay of Bengal & 20 to 100 & Nair et al. (2008) \\
Indian Ocean & $<20$ & Jayaraman et al. (1998) \\
Southern Ocean & 15 to 60 & Moorthy et al. (2005b) \\
\hline
\end{tabular}

\subsection{Number size distributions}

From the individual mass size distribution obtained from the QCM measurements, the daily mean number size distribution (NSD) were determined (Pillai and Moorthy, 2001) and averaging them over the study period, mean representative NSD for Maitri and LH were estimated. These are shown in a loglog scale, in Fig. 8. The low resolution (in size) of the QCM does not bring out any fine features in the size spectrum, and at both locations the NSD showed a rather monotonic decrease in number concentrations (with increase in particle size) which could be parameterized using an inverse powerlaw distribution of the form

$n(r)=C r^{-v}$

where as $C$ is a constant which depends on the total number of particles. The size index $v$ was estimated by a regression fit of Eq. (2) to the mean NSD. The size indices estimated from the individual QCM measurements varied from 3.4 to 3.8 with an average value of $3.6 \pm 0.1$ at Maitri where as it ranged from 3.1 to 3.7 with mean of $3.5 \pm 0.3$ at $\mathrm{LH}$. This indicates that on an average the size distributions of ambient aerosols were quite similar at the two locations; which is in contrast to the feature seen with columnar AOD earlier. Considering the columnar size distributions of the aerosols to follow a form given in Eq. (2), Angstrom exponent $\alpha$ (estimated from Eq. 1) and the size index $v$ (estimated from Eq. 2) could be related by the expression

$v=\alpha+3$

In such case, a comparison of $v$ values estimated from AOD spectral index $\alpha$ and from the QCM measurements could be used to qualitatively infer on the vertical homogeneity of the aerosol size distribution. This has been done in Fig. 9, which shows the temporal variation of the daily mean value

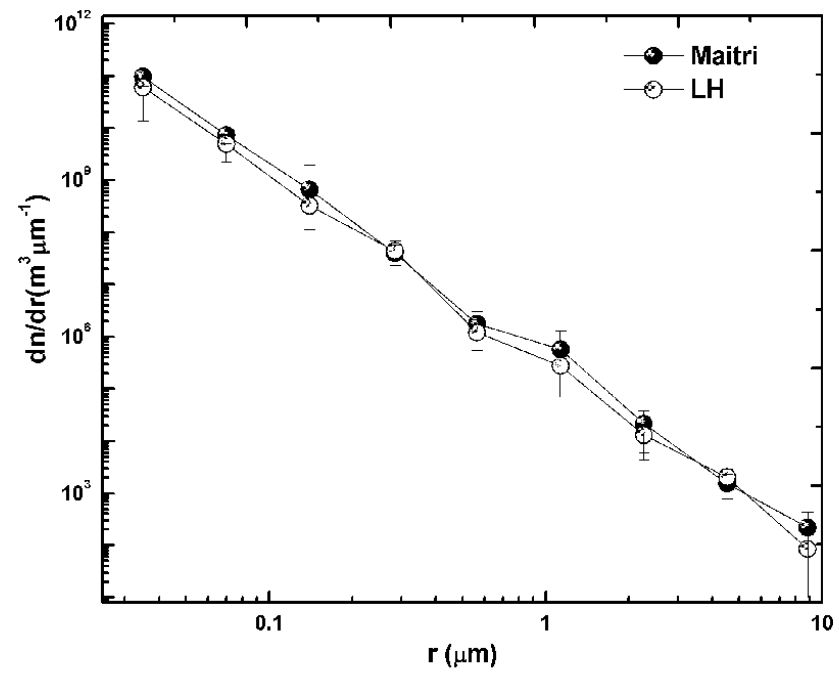

Fig. 8. Aerosol number size distributions for Maitri and LH estimated from QCM measurement. The solid circles are for Maitri where as open circles are for the Larsemann Hills region.

of $v$ from $\alpha$ values (obtained from columnar AOD) shown as open circles and those obtained from QCM values, shown solid circles. It emerges from the figure that over Maitri, the size index $v$ estimated from $\alpha$ is significantly higher than that seen near the surface, which in turn suggests the presence of significant abundance of fine and accumulation mode aerosols aloft (above the Antarctic boundary layer) at Maitri. In other words, the mean size distribution of aerosols in vertical column differed significantly from that seen near the surface at Maitri for the most of the period, except towards the end of study period, after a long and intense blizzard event. This is examined in detail subsequently. Such a feature was not seen at $\mathrm{LH}$, during the study period. 


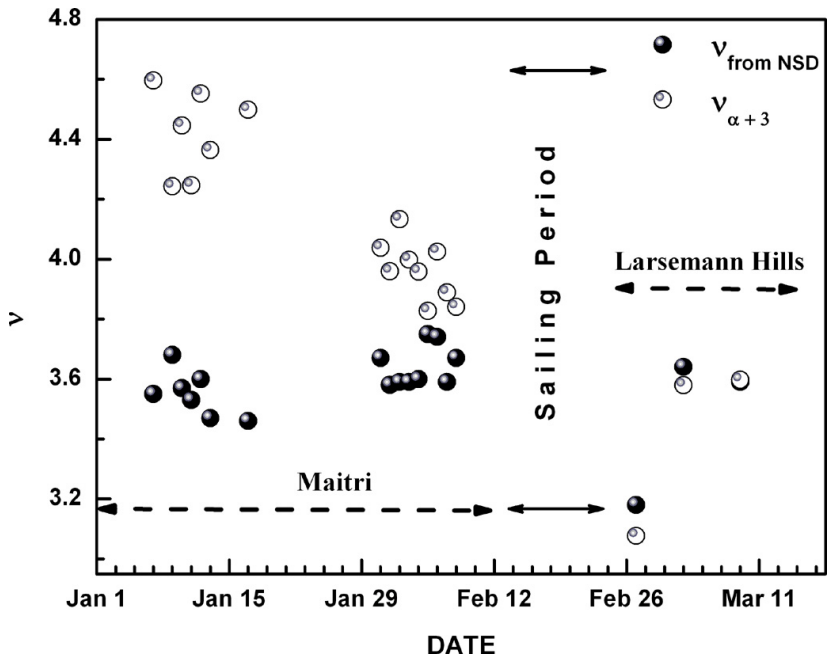

Fig. 9. Temporal variation of the daily mean values of the size in$\operatorname{dex}(v)$ from $\alpha$ values (obtained from spectral values of columnar AOD) and those obtained from number size distribution retrieved from quartz crystal microbalance impactor.

\section{Effect of blizzards and snow scavenging on aerosol properties}

Scavenging of the aerosol particles in the Antarctic atmosphere occurs mainly by the blizzards, accompanied by snowfall, and snow or ice drift, which are more frequent in winter than in summer. Snowfall is the only type of precipitation over Antarctica, and wind generated snow or ice particles in the atmosphere are also good scavengers of the aerosol particles. While the snowfall is a good scavenger at higher altitudes of the atmosphere, the snow or ice drift mainly contributes in the removal of near surface aerosols. At Maitri, a long blizzard event (20 January to 28 January 2008) occurred during the study period and we examined the impact of this on the measured and derived aerosol properties in Fig. 10. In this figure we show AOD, $\alpha, \beta$ and $M_{\mathrm{T}}$ in four panels respectively from the top to bottom. In each panel, the points are the daily mean values, the vertical bars through them are the standard deviation and the horizontal lines represent the mean value of the parameter before and after the blizzard and the thick error bar is the respective standard error. The duration of the blizzard is shown by double headed arrow in each panel. The figure clearly shows that the effect of blizzard is clearly discernible in the columnar AODs, which dropped significantly after the event. Prior to the blizzard AOD varied in range 0.032 to 0.046 giving an average of $0.038 \pm 0.006$, which reduced to be in the range of 0.026 and 0.039 giving an average of $0.031 \pm 0.03$ after the blizzard. In fact the drop is much more if we consider the AODs for the days just before the blizzard onset (AOD 0.042) and the day immediately after the blizzard (0.030). The mean AOD value remained low even after a week and became compa-

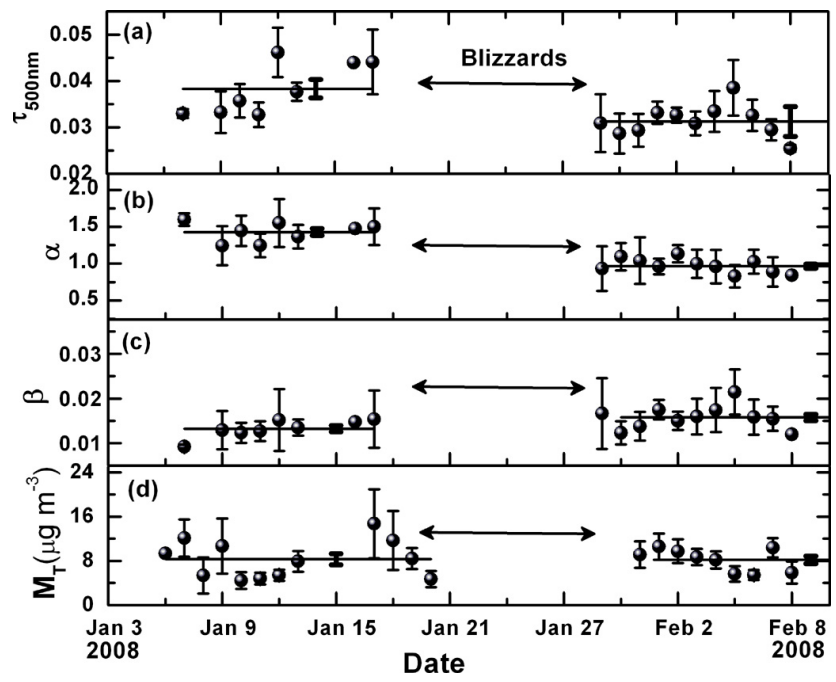

Fig. 10. Aerosols optical depth $(\tau)$, Angstrom exponent $\alpha$, columnar loading " $\beta$ " and total mass concentration $\left(M_{\mathrm{T}}\right)$ before and after the blizzard at Maitri. The vertical line passing through the circles are the standard deviation from the mean value whereas the horizontal line represents the mean value before and after the blizzard event whereas the thick vertical line is the standard error.

rable to the values at $\mathrm{LH}$, showing that the snow scavenging has cleaned the environment over Maitri significantly particularly at higher levels. Examining the other parameters, it is interesting to note that, $\alpha$ showed a significant reduction after the event indicating a substantial washout of the fine and accumulation mode aerosols from the column. The presence of large ice crystals in the Antarctic atmosphere following a blizzard (Tomasi et al., 2007) also would have contributed to flatter AOD spectra after the blizzard. The low mean temperatures prevailing after the blizzard period (below $0{ }^{\circ} \mathrm{C}$; Fig. 3), would favor the formation of such ice crystals in the atmosphere. However, $\beta$, which corresponds to AOD at $1 \mu \mathrm{m}$, did not show remarkable changes. In the case of $M_{\mathrm{T}}$, the variations within a day were higher before the blizzard. After the blizzard even though there was no significant drop in the mean value, the intra-day variation became smaller. This could be due to the prevalence of the local station activities, which maintains a steady flux of aerosols input to the atmosphere, replenishing the particles that were removed from the atmosphere. After the blizzard the movement and transport were restricted in and around Maitri due to snow or ice cover and this would have resulted in reduction of the wind produced dust from ground, which may result in the reduction of the variability during the day. However, these aspects need more investigations after the blizzards to characterize appropriately. Our studies show that there was a significant change in the aerosol size characteristics, and columnar abundance after the blizzard, resulted into the reduction of AOD and Angstrom exponent $\alpha$. 


\section{Summary and conclusions}

Spectral aerosol optical depth (AOD) and total as well as size segregated mass concentrations of ambient aerosols have been studied at two Indian stations in Antarctica, Maitri and Larsemann Hills (LH), in southern hemispheric summer, during the 27th Indian Scientific Expedition to Antarctica. Our investigations over these locations have revealed that:

1. Mean AOD over Maitri $(0.034 \pm 0.005)$ is comparable to that at LH $(0.032 \pm 0.006)$, showing the spatial homogeneity in aerosol properties over the Antarctic atmosphere. On the other hand, AOD measured at Amsterdam and Crozet Island in Southern Ocean was significantly higher and variable than that over Maitri and LH.

2. Spectral variations are similar for LH, Amsterdam Island and Crozet Island but differ significantly form Maitri. Estimated $\alpha$ showed a fine mode dominance at Maitri $(\alpha \sim 1.2)$ and coarse mode dominance at $\mathrm{LH}$ $(\alpha \sim 0.7)$, Amsterdam and Crozet Islands.

3. Air mass back trajectories obtained for the full summer and autumn period (1 December 2007 to 31 March 2008) showed that, aerosols properties over both the sampling location are modified by wind coming from the high latitude polar region. With the increased tourism and scientific activities during summer, there can be a large day to day variability in the aerosol, characteristics at coastal Antarctica due to the air mass coming at the stations from inland continental stations.

4. Blizzard resulted into the reduction of $\mathrm{AOD}$ and Angstrom exponent $\alpha$ over Maitri where as total mass concentration $M_{\mathrm{T}}$ remained more or less same. This needs to be investigated in detail for delineating the local effects in the ambient aerosol concentrations.

Acknowledgements. This experiment was conducted as a part of the Aerosols Radiative Forcing over India (ARFI) project of ISROGeosphere Biosphere Programme. We thank Director, National Centre for Antarctic and Oceanic Research, Goa, expedition leader Arun Chaturvedi, voyage leader Ajay Dhar and Anoop Tiwari of NCAOR for providing the necessary support for carrying out the experiments. We thank B. N. Holben, Jean Sciare and their staff for establishing and maintaining the Crozet Island and Amsterdam Island sites used in this investigation. The authors gratefully acknowledge the NOAA Air Resources Laboratory for the provision of the HYSPLIT transport and dispersion model used in this paper. We thank Indian Metrological Department for providing the metrological data at Maitri.

Topical Editor P. M. Ruti thanks two anonymous referees for their help in evaluating this paper.

\section{References}

Angstrom, A.: The parameters of atmospheric turbidity, Tellus, XIVV(14), 64-75, 1964

Argentini, S., Viola, A., Sempreviva, A., and Petenko, I.: Summer PBL height at the plateau site of Dome C, Antarctica, Bound. Lay. Meteorol., 115(3), 409-422, 2005.

Bodhaine, B. A.: Aerosol absorption measurements at Barrow, Mauna Loa and South Pole, J. Geophys. Res., 100, 8967-8975, 1995.

Chaubey, J. P., Moorthy, K. K., Babu, S. S., Nair, V. S., and Tiwari, A.: Black Carbon aerosols over Coastal Antarctica and its scavenging by snow during the Southern Hemispheric Summer, J. Geophys. Res., 115, D10210, doi:10.1029/2009JD013381, 2010.

Chylek, P. and Coakley Jr., J. A.: Aerosols and climate, Science, 183, 75-77, 1974.

Fitzgerald, J. W.: Marine Aerosols: A review, Atmos. Environ., 25A, 533-545, 1991.

Gadhavi, H. and Jayaraman, A.: Aerosol characteristics and aerosol radiative forcing over Maitri, Antarctica, Current Sci., 86(2), 296-304, 2004.

Hall, J. S. and Wolff. E. W.: Causes of seasonal and daily variations in aerosol sea-salt concentrations at a coastal Antarctic station, Atmos. Environ., 32, 3669-3677, 1998.

Hansen, J. and Nazarenko, L.: Soot Climate Forcing via Snow and Ice Albedos, P. Natl. Acad. Sci. USA, 101, 423-428, 2004.

Hansen, A. D. A., Lowenthal, D. H., Chow, J. C., and Watson, J. G.: Black carbon aerosol at McMurdo station, Antarctica, Journal of Air and Waste Management Association, 51, 593-600, 2001.

Hara, K., Osada, K., Kido, M., Matsunaga, K., Iwasaka, Y., Hashida, G., and Yamanouchi, T.: Variations of constituents of individual sea-salt particles at Syowa station, Antarctica, Tellus, Ser. B, 57, 230-246, 2005.

Hara, K., Osada, K., Yabuki, M., Hayashi, M., Yamanouchi, T., Shiobara, M., and Wada, M.: Measurement of black carbon at Syowa station, Antarctica: seasonal variation, transport processes and pathways, Atmos. Chem. Phys. Discuss., 8, 98839929, doi:10.5194/acpd-8-9883-2008, 2008.

Hatzianastassiou, N., Fotiadi, A., Matsoukas, Ch., Pavlakis, K., Drakakis, E., Hatzidimitriou, D., and Vardavas, I.: Longterm global distribution of earth's shortwave radiation budget at the top of atmosphere, Atmos. Chem. Phys., 4, 1217-1235, doi:10.5194/acp-4-1217-2004, 2004.

Herber, A., Thomason, L. W., Radianov, V. F., and Leiterer, U.: Comparison of trends in the tropospheric and stratospheric aerosol optical depth in the Antarctic, J. Geophys. Res., 98(D10), 18441-18447, 1993.

Hogan, A. W., Barnard, S., and Bortiniak, J.: Physical properties of the aerosol at the South Pole, Geophys. Res. Lett., 6, 845-848, 1979.

Holben, B. N., Eck, T., Slutsker, I., Tanre, D., Buis, J. P., Setzer, A., Vermote, E., Reagan, J. A., Kaufmann, Y. J., Nakajima, T., Lavenu, F., Jankowiak, I., and Smirnov, A.: AERONET - A federated instrument network and data archive for aerosol characterization, Remote Sensing of the Environment, 66, 1-16, 1998.

Ichoku, C., Levy, R., Kaufman, Y. J., Remer, L. A., Li, R. R., Martins, V. J., Holben, B. N., Abuhassan, N., Slutsker, I., Eck, T. F., and Pietras, C.: Analysis of the performance characteristics of the five-channel Microtops II Sun Photometer for measuring aerosol optical thickness and perceptible water vapour, J. Geo- 
phys. Res., 107, D13, doi:10.1029/2001JD00130, 2002.

Intergovernmental Panel for Climate Change 2007: Changes in Atmospheric Constituents and in Radiative Forcing, Contribution of working group to the fourth assessment report of the IPCC (New York: Cambridge Univ. Press), 2007.

Jayaraman, A., Lubin, D., Ramachandran, S., Ramanathan, V., Woodbridge, E., Collins, W. D., and Zalpuri, K. S.: Direct observations of aerosol radiative forcing over the tropical Indian Ocean during the January-February 1996 pre-INDOEX cruise, J. Geophys. Res., 103, 13827-13836, 1998.

Jourdain, B. and Legrand, M.: Year-round records of bulk and size segregated aerosol composition and $\mathrm{HCl}$ and $\mathrm{HNO}_{3}$ levels in the Dumont d'Urville (coastal Antarctica) atmosphere: Implications for sea-salt aerosol fractionation in the winter and summer, J. Geophys. Res., 107(D22), 4645, doi:10.1029/2002JD002471, 2002.

King, J. C. and Turner, J.: Antarctic climatology and meteorology, Cambridge University Press., 1997.

Lilijequist, G. H.: Energy Exchange of an Antarctic Snowfield. Short- Wave Radiation. Norwegian-British-Swedish Antarctic Expedition 1949-1952: Scientific Results, vol. II, part 1A, 109 pp., Norwegian Polar Institute, Oslo, 1957.

Mazzera, D. M., Douglas, H. L., Chow, J. C., Watson, J. G., and Grubisic, V.: PM10 measurements at McMurdo Station, Antarctica, Atmos. Environ., 35, 1891-1902, 2001.

Minikin, A., Legrand, M., Hall, J., Wagenbach, D., Kleefeld, C., Wolff, E., Pasteur, E. C., and Ducroz, F.: Sulfur-containing species (sulfate and methanesulfonate) in coastal Antarctic aerosol and precipitation, J. Geophys. Res., 103, 10975-10990, 1998.

Moorthy, K. K. and Satheesh, S. K.: Characteristics of aerosols over a remote island, Minicoy in the Arabian Sea: Optical properties and retrieved size characteristics, Q. J. Roy. Meteor. Soc., 126, 81-109, 2000.

Moorthy, K. K., Satheesh, S. K., and Krishna Murthy, B. V.: Investigations of marine aerosols over the tropical Indian Ocean, J. Geophys. Res., 102, 18827-18842, 1997.

Moorthy, K. K., Sunilkumar, S. V., Pillai, P. S., Parameswaran, K., Nair, P. R., Ahmed, Y. N., Ramgopal, K., Narasimhulu, K., Reddy, R. R., Vinoj, V., Satheesh, S. K., Niranjan, K., Rao, B. M., Brahmanandam, P. S., Saha, A., Badarinath, K. V. S., Kiranchand, T. R., and Latha, K. M.: Wintertime spatial characteristics of boundary layer aerosols over Peninsular India, J. Geophys. Res., 110, D08207, doi:10.1029/2004JD005520, 2005 a.

Moorthy, K. K., Satheesh, S. K., Babu, S. S., and Saha, A.: Large latitudinal gradients and temporal heterogeneity in aerosol black carbon and its mass mixing ratio over southern and northern oceans observed during a trans-continental cruise experiment, Geophys. Res. Lett., 32, L14818, doi:10.1029/2005GL023267, $2005 b$

Morys, M., Mims, F. M., Hagerup, S., Anderson, S. E., Baker, A., Kia, J., and Walkup, T.: Design, calibration and performance of MICROTOPS II hand-held ozone monitor and Sun Photometer, J. Geophys. Res., 106(D13), 14573-14582, 2001.

Muller, D., Franke, K., Wagner, F., and Heintzenberg, J.: Vertical profiling of optical and physical particle properties over the tropical Indian Ocean with six-wavelength lidar 2. Case studies, J. Geophys. Res., 106, 28577-28595, 2001.

Nair, V. S., Babu, S. S., and Moorthy, K. K.: Aerosol characteristics in the marine atmospheric boundary layer over the Bay of Bengal and Arabian Sea during ICARB: Spatial distribution and latitudinal and longitudinal gradients, J. Geophys. Res., 113, D15208, doi:10.1029/2008JD009823, 2008.

Niemi, J. V., Tervahattu, H., Virkkula, A., Hillamo, R., Teinil, K., Koponen, I. K., and Kulmala, M.: Continental impact on marine boundary layer coarse particles over the Atlantic Ocean between Europe and Antarctica, Atmos. Res., 75, 301-321, 2005.

O'Dowd, C. D., Smith, M. H., Consterdine, I. E., and Lowe, J. A.: Marine aerosol, sea salt, and the marine sulphur cycle, Atmos. Environ., 31, 73-80, 1997.

Osada, K., Hayashi, M., Ui, H., and Iwasaka, Y.: Ionic constituents in aerosol particles at Syowa station, east Antarctica, during 1996, Polar Meteorology Glaciology, 12, 49-57, 1998.

Pillai, P. S. and Moorthy, K. K.: Aerosol mass-size distributions at a tropical coastal environment: Response to mesoscale and synoptic processes, Atmos. Environ., 35, 4099-4112, 2001.

Porter, J. N., Miller, M., Pietras, C., and Motell, C.: Ship based sun photometer measurements using Microtops sun photometer, J. Atmos. Oceanic Technol., 18, 765-744, 2001.

Preunkert, S., Jourdain, B., Legrand, M., Udisti, R., Bevagli, S., and Cerri, O.: Seasonality of sulfur species (dimethyl sulfide, sulfate, and methanesulfonate) in Antarctica: Inland versus coastal regions, J. Geophys. Res., 113, D15302, doi:10.1029/2008JD009937, 2008.

Radionov, V. F.: Variability of aerosol extinction of solar radiation in Antarctica, Antarctic Science, 6(3), 419-424, 1994.

Randles, C. A., Russell, L. M., and Ramaswamy, V.: Hygroscopic and optical properties of organic sea salt aerosol and consequences for climate forcing, Geophys. Res. Lett., 31, L16108, doi:10.1029/2004GL020628, 2004.

Russell, P. B., Redemann, J., Shimid, B., Bergstrom, R. W., Livingston, J. M., Mcintosh, D. M., Ramirez, S. A., Hartley, S., Hobbs, P. V., Quinn, P. K., Carrico, C. M., Rood, M. J., O'stro'm, E., Noone, K. J., Hoyningen-Huene, W. V., and Remer, L.: Comparison of Aerosol Single Scattering Albedos Derived by Diverse Techniques in Two North Atlantic Experiments, J. Geophys. Res., 59, 609-619, 2002.

Satheesh, S. K., Moorthy, K. K., Babu, S. S., Vinoj, V., and Dutt, C. B. S.: Climate implications of large warming by elevated aerosols over India, Geophys. Res. Lett., 33, L20816, doi:10.1029/2008GL034944, 2008.

Savoie, D. L., Prospero, J. M., Larsen, R. J., and Saltzman, E. S.: Nitrogen and sulfur species in aerosols at Mawson, Antarctica and their relationship to natural radionuclides, J. Atmos. Chem., 14, 181-204, 1992.

Savoie, D. L., Prospero, J. M., Larsen, R. J., Huang, F., Izaguirre, M. A., Huang, T., Snowdon, T. H., Custals, L., and Sanderson, C. G.: Nitrogen and sulfur species in Antarctic aerosols at Mawson, Palmer station and Marsh (King George Island), J. Atmos. Chem., 17, 95-122, 1993.

Schwartz. S. E. and Andreae, M. O.: Uncertainty in climate change caused by aerosols, Science, 272, 1121-1122, 1996.

Shaw, G. E.: Consideration on the origin and optical properties of the antarctic aerosol, Review of Geophysics and Space Sciences, 17, 1983-1998, 1979.

Shaw, G. E.: Atmospheric turbidity in the polar regions, J. Appl. Meteorol., 21, 1080-1088, 1982.

Shaw, G. E.: Antarctic aerosols: A review, Rev. Geophys., 26, 89- 
$112,1988$.

Shirsat, S. V. and Graf, H. F.: An emission inventory of sulfur from anthropogenic sources in Antarctica, Atmos. Chem. Phys., 9, 3397-3408, doi:10.5194/acp-9-3397-2009, 2009.

Six, D., Fily, M., Blarel, L., and Goloub, P.: First aerosol optical thickness measurements at Dome C (East Antarctica), summer season 2003-2004, Atmos. Environ., 39, 5041-5050, 2005.

Smirnov, A., Holben, B. N., Kaufman, Y. J., Dubovik, O., Eck, T. F., Slutsker, I., Pietras, C., and Halthore, R. N.: Optical properties of atmospheric aerosol in maritime environment, J. Atmos. Sci., 59, 501-523, 2002.

Smirnov, A., Holben, B. N., Sakerin, S. M., Kabanov, D. M., Slutsker, I., Chin, M., Diehl, T. L., Remer, L. A., Kahn, R., Ignatov, A., Liu, L., Mishchenko, M., Eck, T. F., Kucsera, T. L., Giles, D., and Kopelevich, O. V.: Ship-based aerosol optical depth measurements in the Atlantic Ocean: Comparison with satellite retrievals and GOCART model, Geophys. Res. Lett., 33, L14817, doi:10.1029/2006GL026051, 2006.

Tomasi, C., Vitale, V., Lupi, A., Carmine, C. D., Campanelli, M., Herber, A., Treffeisen, R., Stone, R. S., Andrews, E., Sharma, S., Radionov, V., Hoyningen-Huene, W. von, Stebel, K., Hansen, G. H., Myhre, C. L., Wehrli, C., Aaltonen, V., Lihavainen, H., Virkkula, A., Hillamo, R., Ström, J., Toledano, C., Cachorro, V. E., Ortiz, P., Frutos, A. M. De., Blindheim, S., Frioud, M., Gausa, M., Zielinski, T., Petelski, T., and Yamanouchi, T.: Aerosols in polar regions: A historical overview based on optical depth and in situ observations, J. Geophys. Res., 112, D16205, doi:10.1029/2007JD008432, 2007.

Valero, J. P., Ackerman, T. P., and Gore, W. J. Y.: Radiative effects of the Arctic haze, Geophys. Res. Lett., 10, 1184-1187, 1983.

Viehbrock, H. J. and Flowers, E. C.: Comments on the recent decrease in solar radiation at the South Pole, Tellus, Ser. B, 20, 400-410, 1968.
Vinoj, V. and Satheesh, S. K.: Measurements of aerosol optical depth over Arabian Sea during summer monsoon season, Geophys. Res. Lett., 30(5), 1263-1267, 2003.

Vinoj, V., Anjan, A., Sudhakar, M., Satheesh, S. K., Srinivasan, J., and Moorthy, K. K.: Latitudinal variation of aerosol optical depths from northern Arabian Sea to Antarctica, Geophys. Res. Lett., 34, L10807, doi:10.1029/2007GL029419, 2007.

Virkkula, A., Teinila K., Hillamo R., Kerminen, V. M., Saarikoski, S., Aurela, M., Koponen, I. K., and Kulmala, M.: Chemical size distributions of boundary layer aerosol over the Atlantic Ocean and at an Antarctic site, J. Geophys. Res., 111(D5), D05306, doi:10.1029/2004JD004958, 2006.

Wagenbach, D., Ducroz, F., Mulvaney, R., Keck, L., Minikin, A., Legrand, M., Hall, J. S., and Wolff, E. W.: Sea-salt aerosol in coastal Antarctic regions, J. Geophys. Res., 103, 10961-10974, 1998.

Wall, D. H.: Biodiversity and ecosystem functioning in terrestrial habitats of Antarctica, Antarctic Science, 17(4), 523-531, 2005.

Wehrli, C.: GAWPFR: A network of Aerosol Optical Depth observations with Precision Filter Radiometers, in: WMO/GAW Experts Workshop on a Global Surface Based Network for Long Term Observations of Column Aerosol Optical Properties, GAW Report 162, WMO TD, 1287, pp. 36-39, World Meteorological Organisation, Geneva, Switzerland, 2005.

Weller, R., Wöltjen, J., Piel, C., Resenberg, R., Wagenbach, D., König-Langlo, G., and Kriews, M.: Seasonal aspects of marine and mineral dust derived trace elements in the aerosol at Neumayer Station, Antarctica, Tellus B, 60(5), 742-752, 2008.

Wolff, E. W. and Cachier, H.: Concentrations and seasonal cycle of black carbon in aerosol at a coastal Antarctic station, J. Geophys. Res., 103, 11033-11041, 1998. 